\title{
Pollen as a Forensic Tool in a Zone of Wetlands from Buenos Aires, Argentina
}

\author{
Lilian M Passarelli* and Romina Mori Cortes
}

Laboratory of Evolutionary and Systematic Plant Anatomy Studies (LEAVES), Faculty of Natural Sciences and Museum of La Plata, National University of La Plata, Argentina.

*Correspondig author: Lilian M Passarelli, Laboratory of Evolutionary and Systematic Plant Anatomy Studies (LEAVES), Universidad Nacional de La Plata, La Plata, Buenos Aires, Argentina, Tel: +54-221-42-49049; E-mail: 1mpassarelli@yahoo.com.ar

Received date: Jan 03, 2017; Accepted date: January 26, 2017; Published date: January 31, 2017

Copyright: (c) 2017 Passarelli LM, et al. This is an open-access article distributed under the terms of the Creative Commons Attribution License, which permits unrestricted use, distribution, and reproduction in any medium, provided the original author and source are credited.

\section{Abstract}

Forensic Palynology is an important tool to resolve the place and sometimes the season of the year of a fact. The palynomorphs may be in different objects (clothes, shoes, ropes). Pollen morphology is sometimes exclusive for a plant species and some of them grow in specific areas besides plants produce pollen at certain times of the year. The study was based on field work and monitoring seasonal wild communities near Punta Lara reserve. This paper describes the pollen morphology of the representative species which grow in this zone of wetlands from Buenos Aires, Argentina and can be representative of the landscape of the region.

Keywords: Pollen; Forensic science; Palynology; Crime scene; Wetlands

\section{Abbreviations: SEM: Scanning Electron Microscopy}

\section{Introduction}

Pollen is an important tool to recognize the site of a fact and it may contribute to the moment, too. Pollen morphology is sometimes exclusive for a plant species and some of them grow in specific areas besides plants produce pollen at certain times of the year [1-6]. A new A new broader term, Forensic Ecology, includes information about sampling strategies for diatom analysis, pollen and soils samples and entomology [7].

In 1959 a murder placed at the herbarium of the Swedish Museum of Natural History was elucidated by the presence of pollen grains of Trifolium pratense and spores of a phycomycete, Endogene [8,9], cultivations areas of Cannabis sp. were detected by the analysis of the pollen associated with the cultivation areas of this drug [5,9]. Several cases were solved through palynology [10], but still it is necessary to spread its importance due to in many countries the court do not know it.

In Argentina, a country with extensive latitude and longitude, there are different phytogeographic regions that can be differentiated by their flora, these phytocoenoses show the association of these plants growing together and brings important data $[11,12]$.

In the Pampean region the vegetation is very heterogeneous, mainly plains or prairies with few lagoons scattered in it. On the northeastern margin is the Rio de la Plata, an area that changes the landscape for its jungles in gallery. This marginal forest belongs to the phytogeographical district of the mixed forests of the Paraná phytogeographic province, and its species descend through the jungle galleries bordering the Uruguay river, and to a much lesser extent the Paraná river from Misiones province [12-15]. In this place because of its landscape, to be a protected area with scarce human settlements and more easily to hide, have appeared several bodies without life [16-18].
The objective of this work is to provide the floristic data of the most representative species and the pollen morphology of some of them.

\section{Materials and Methods}

The study was based on field work and monitoring seasonal wild communities near Punta Lara reserve, during four years. Plants specimens were obtained and send to the LEAVES herbarium. For SEM observations, pollen samples were mounted without treatment on metal stubs with adhesive double sided tape, covered with gold/ palladium under vacuum, and examined by a Jeol T100 microscope of the Electronic Microscopy Service from the Facultad de Ciencias Naturales y Museo, Universidad Nacional de La Plata, Argentina.

\section{Results}

Eight botanical families were selected in this area because they presented interesting pollen morphology due to the possibility of recognizing the plants from which the pollen samples originated. They are: Alismataceae, Commelinaceae, Fabaceae, Iridaceae, Lytharaceae, Malpighiaceae, Marantaceae and Pontederiaceae.

Alismataceae (Sagittaria motevidensis L): It is a species of flowering plant, widespread in wetlands. Grows in marshes, ponds, shallow and slow-flowing waters. Common in scrublands and streams of the Argentine river coast. Pollen is pantoporate with pores around the surface of the exine. It also has spines arranged homogeneously. (Figure 1A)

Commelinaceae (Commelina diffusa): It is a common plant in humid and shady places. Pollen with a single longitudinal opening, sulcus, has spines as ornamentation (Figure 1B)

Fabaceae (Erythrina crista galli L): It is found in low floodplain areas, and along the watercourses. It does not inhabit high forest or dry sites without floods, it tolerates very well water-saturated soils; It is very common in this region (Figure 1C). Pollen with three apertures, triporate, with rugulate ornamentation. 


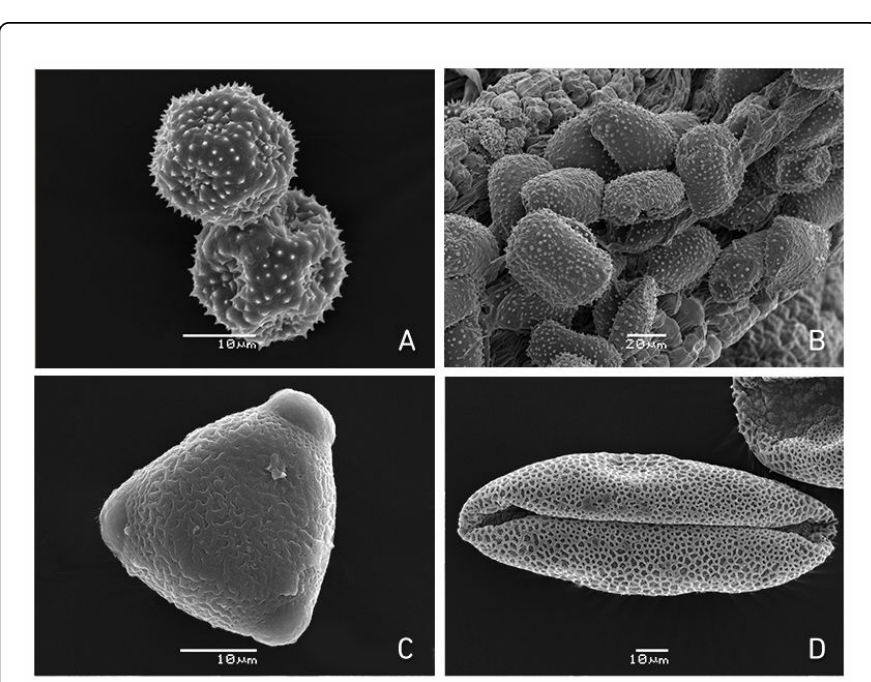

Figure 1: Pollen grains SEM photographs. A: Sagittaria motevidensis, B: Commelina diffusa, C: Erythrina crista galli; D: Iris pseudacorus.

Iridaceae (Iris pseudacorus L) appears in the margin of water courses of certain depths, flowers appear only near July or August to September, and grows well in very humid conditions, is common to find it in marshes, where it tolerates immersion, low $\mathrm{pH}$, and anoxic soils. Pollen with a single longitudinal opening, sulcus, reticulate with heterogeneous reticulum.

Lytharaceae (Cuffea fruticosa Spreng): Its habitat is wetlands and marshes on the waterfront. It is native to South America subtropical perennial grass. Pollen tricolporate, commonly with a striate ornamentation. The longitudinal aperture reaches the poles of the pollen grain joining (Figure $2 \mathrm{~A}$ )

Malpighiaceae (Stigmatophyllum littorale A Juss) is a climbing grass which can grow between 3 to 5 meters in height, supported by other species. It grows in Buenos Aires province in the riverside zone, in the edges of marginal forests and in hygrophilous forests. The pollen is pantoporate with rugulate ornamentation (Figure 2B)

Marantaceae (Thalia geniculata L): It is distributed in marshy areas, flooded, or edges of river courses, warm regions. Pollen grains vary simple, spheroidal, without apertures and without onamentation (Figure 2C).

Pontederiaceae (Pontederia rotundifolia L): It is a floating plant that inhabits marshes such as swamps and uncrowded rivers. In the province it is found in the zone of the Delta and coast of Río de La Plata. Pollen grains with boat shape, negative ornamentation formed by foveas (Figure 2D).

\section{Discussion}

The pollen grains morphology and characteristics studied in this work confirm their importance as indicators of a wetland environment. The presence of any of them would be relating the place of the fact to the suspects. The region where these plants grow is well delimited and separates from other nearby with very different vegetation allowing identify the area without doubt. There are many works on pollen of aquatic angiosperms that demonstrate the great diversity that they exhibit in pollen characters, such as types of apertures and sporoderm structure; we can add shape, size and polarity [19].

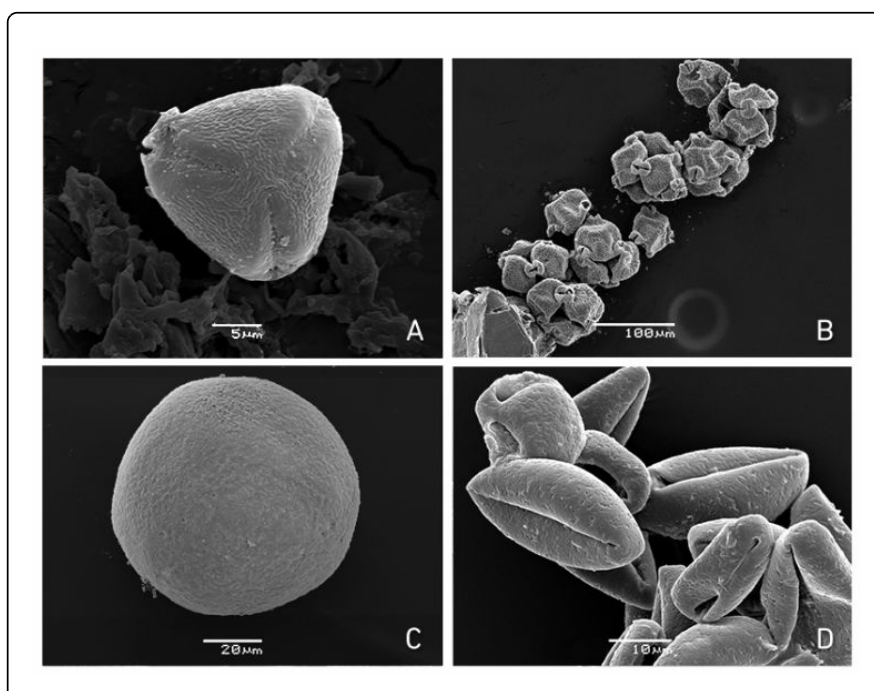

Figure 2: Pollen grains SEM photographs, A: Cuffea fruticosa; B: Stigmatophyllum littorale, C: Thalia geniculate, D: Pontederia rotundifolia.

Several authors have been able to determine that rare or unique species for a geographical area easily confirm the origin of the material; they explain that DNA evidence is sometimes needed [20]. Additionally Sanchez et al. [10] have shown that on very close areas of different vegetation the polynic analysis is valid as a method because there is correlation between the pollen spectra of samples in each locality and the pollen present in shoes and on the surface sediment, which suggests that the sediment housed in the sole of the shoe represents the precise delimitation of an important environment in of the forensic context [21].

Environmental profiling have also provided in war crimes the original areas of the graves and relate the relocated bodies to the original burial sites, sometimes also the execution sites [22].

It is important to make pollen diagrams that show the correlation between the current vegetation and the pollen obtained from the analyzed samples. Forensic palynology has presented many evidences of its value as any other forensic tool, since the 60's has grown a lot and is increasing day by day; this allows it to be increasingly recognized.

\section{Acknowledgement}

This work was conducted at the Laboratorio de Estudios de Anatomía Vegetal Evolutiva y Sistemática (LEAVES), Facultad de Ciencias Naturales y Museo de La Plata; supported by the Programa de Incentivos para Docentes Investigadores de la Universidad de La Plata, and the Proyecto de Desarrollo Tecnológico y Social, PDTS 120. The authors gratefully acknowledge Prof. Patricia Sarmiento for Scannig Electron Microscopy (SEM) photograph assistance. The authors also thank graphic designer Marcos G. Moreno, who carefully prepared the illustrations. We are greatly indebted to the reviewers for their careful evaluation and for the contribution that improve the manuscript, too. 
Citation: Passarelli LM, Cortes RM (2017) Pollen as a Forensic Tool in a Zone of Wetlands from Buenos Aires, Argentina. J Forensic Res 8: 366. doi:10.4172/2157-7145.1000366

Page 3 of 3

\section{References}

1. Bryan VM Jr. (1989) Pollen: Nature's Fingerprints of Plants In: (1990) Yearbook of Science and the Future, Encyclopedia Britannica. Encycl Britannica Inc, Chicago, Illinois pp: 92-111.

2. Bryant VM Jr, Jones JG, Mildenhall DC (1990) Forensic Palynology in the United States of America. Palynol 14: 193-208.

3. Bryant VM (2009) Palynology In: Jamieson A and Moenssens A (Eds.), Wiley Encyclopedia of Forensic Science, Wiley, Portsmouth, UK pp: 1954-1968.

4. Mildenhall DC (1982) Forensic palynolology. Geoscience Society of NZ 58: 25 .

5. Mildenhall DC (1990) Forensic palynology in New Zealand. Rev Paleob Palynol 64: 227- 234.

6. Mildenhall DC, Wiltshire PE, Bryant VM (2006) Forensic palynology: Why do it and how it works. Forensic Scie Int 163: 163-172.

7. Márquez-Grant N, Roberts J (2012) Forensic Ecology Handbook: From Crime Scene to Court, John Wiley \& Sons Inc., USA.

8. Erdtman G (1963) Palynology. Adv Bot Res 1: 149-220.

9. Wu Ch L, Yang Ch H, Huang T, Chen S (2006) Forensic pollen evidence from clothes by the tape adhesive method. Taiwania 51: 123-130.

10. Martínez-Sánchez M, Fernández S, Carrión J (2008) Palynology and forensic scenario. A case study from the southeast of Spain. Anales de Biología 30: 43-54.

11. Cabrera AL (1976) Phytogeographical Territories of the Argentine Republic. Enc. Argentina by Agric. and Gardening, ACME, Buenos Aires, Argentina pp: 2-85.
12. Passarelli L, Rolleri C, Ciciarelli M, Dedomenici A, González G (2014) Flora vascular de humedales permanentes y transitorios bonaerenses (Buenos Aires, Argentina). Bot Complut 38: 139-154.

13. Cabrera A, Dawson G (1944) The Marginal Forest of Punta Lara. Revista Mus La Plata Botánica pp: 267-382.

14. Cabrera A, Zardini E (1993) Manual of the flora of the environs of Buenos Aires. ACME, Buenos Aires, Argentina.

15. Hernández M, Novoa M, Colares M, Perrotta V, Nughes L, et al. (2015) Leaf anatomy of medicinal herbs growing in the Rio de Janeiro region (Buenos Aires, Argentina). Bonplandia 24: 97-123.

16. Killed in cold blood Ricardo Barreda eliminated his family on Sunday, November 15, 1992. It all ended before noon. Clarín.com, August 13, 2000.

17. Los muertos que nadie reclama (The dead that nobody require). Diario Página April 21th, 2008.

18. Second trial for double crime in Punta Lara. (Second trial for double crime in Punta Lara). Daily Today, October 4th, 2014.

19. Perveen A (1999) A Palynological Survey of Aquatic Flora of KarachiPakistan. Tr J of Botany 23: 309-317.

20. Coyle HM, Lee CH, Lin W, Lee HC, Palmbach T (2005) Forensic botany: Using plant evidence to aid in forensic death investigation. Croat Med J 46: 606-612.

21. Horrocks M, Walsh K (1999) Fine Resolution of pollen patterns in limited space: Differentiating a crime scene and alibi scene seven meters apart. J Forensic Sci 44: 417-420.

22. Brown AG (2006) The use of forensic botany and geology in war crimes investigations in NE Bosnia. Forensic Sci Int 163: 204-210. 